Proceedings of the 2nd international conference Economic and Business Trends Shaping the Future | 2021

\title{
BUSINESS ENGLISH AS THE LINGUA FRANCA IN THE MACEDONIAN COMPANIES - A STRATEGY FOR THE FUTURE
}

\author{
Nikola Dimeski \\ Faculty of Economics - Prilep \\ nikola.dimeski@uklo.edu.mk
}

\begin{abstract}
The progress of society, in all areas, largely depends on the quality and the advancement of the companies in one country. Since the economy of a country is the primary drive for progress, the corporate world must evolve and advance in order to keep up with the trends and the constant changes in the business environment and thus continue the progress of societies. This paper aims to provide an understanding of the importance of business English as a lingua franca in advancing Macedonian businesses. Although the primary purpose for developing business English has been business interaction among English-speaking and non-English speaking companies, with time, the companies have dragged in native languages turning business English into a lingua franca in the corporate world. Therefore, not only has business English progressed into the backbone of international trade, which is crucial for the economic development of the countries, but it also became essential for the companies' internal communication, which is vital for their operation and performance. That being said, the main implication of this paper is to enlighten Macedonian society on the significance of introducing business English as the lingua franca in Macedonian companies. By discussing and analysing specific areas on how business English can improve the competitiveness of the Macedonian companies and workforce, the researcher proposes a strategy for the future based on; introduction of a Business English course in the Macedonian educational system, training of employees, employment of staff conversant with English, use of simple vocabulary and repetition of statements, and embracing language diversity.
\end{abstract}

Keywords: business English, business English as a lingua franca, BELF, English as a lingua franca

JEL classification: $Z 13$

\section{INTRODUCTION}

Communication between individuals with different languages has increased in every feature of life, including in the corporate environment. According to Gerritsen and Nickerson (2009), this is experienced by business organisations with a diverse workforce and international business communication where speakers and stakeholders come from countries that speak different languages. Gerritsen and Nickerson (2009) explain such a commonplace situation in international business using person $\mathrm{A}$ and $\mathrm{B}$. The authors state that four options are available whenever person A uses language A to speak to person $\mathrm{B}$, who uses language $\mathrm{B}$. The first and second option is that these two people can decide to use either language A or language B. The third option is that both speakers can decide to use their first language. The last option is that both speakers can opt for a 
third language known as language $C$. Language $C$ is a neutral language that both speakers, in this case, person $\mathrm{A}$ and person $\mathrm{B}$, can speak and understand each other. In most cases, this language $\mathrm{C}$ is the one known as a lingua franca. An example of a lingua franca can be business English.

Over the last two decades, most organisations have opted to use English as a dominant language in international businesses. According to Martins (2017), the English language is used by almost 91\% of employers in international companies worldwide. It is clear that English is the most common and widely used language in business and international relations. English language in Macedonia is reflected in most business organisations that use English as their cooperate language. All these companies choose to report all their documents in English and communicate between different departments in English.

Since the early 1990s, Dimeski (2016) explains that companies in Macedonia have experienced massive economic and technological transitions. These changes and developments have brought the need to expand the languages used in Macedonian companies for an extensive and better form of communication. Although most people are studying the language, business English puts pressure on employees, particularly those involved in international business. Also, many organisations have failed in diversifying their operations to other nations due to the essential language issue. An OECD Research on Innovating Education in 2016 analyses that some multinationals only focus on markets with a common language, which is a huge limitation for many developing countries, not only for the companies. In order to improve communication and satisfy the desires of the consumers, Macedonian companies should feel the need to implement business English as a lingua franca as they interact with the rest of the world. This paper focuses on the benefits and importance of introducing business English as the lingua franca in Macedonian companies as a strategy for the success of Macedonian society in the future.

\subsection{Definition of key terms}

Sharma (2020) defines business English (BE) as the "nucleus of business"; thus, an organisation incorporating business English in its culture has business leverage.

Business English as a lingua franca (BELF) is defined as a neutral language of communication between business people whose English is not their first language.

Lingua franca is a tool of communication used by people from diverse native languages.

\section{LITERATURE REVIEW}

The literature review section discusses the concept of business English, business English as a lingua franca, the importance of introducing business English as a lingua franca in companies, and how the introduction of business English in learning institutions can promote business English as a lingua franca in companies.

\subsection{Business English}

Business English (BE) is the language used in the business industries, and thus, every individual in the corporate world should learn it (Nickerson and Planken, 2015, p.24). Although it is sometimes perceived that business English is the same as the general English language, this is not the case because someone may be fluent in general English but have difficulties understanding and using business English. There is a wide range of definitions regarding the BE, which shows that the term is understood differently. Most of the time, the way BE is defined depends on 
personal characteristics and needs. For example, Dimeski (2016) says that people looking for jobs understand business English as something they should know to acquire a job. On the other hand, business English represents a specific field of the international English language for people with English as their common language. Therefore, the definition of business English depends on the individual perception and the goal aimed to be achieved in the end. Mainly, people from nonEnglish speaking nations are the ones who learn to use it when doing business with people from English-speaking countries.

Business English is also known as the corporate language. Corporate language refers to the language used in the corporate world for performing business transactions among business entities. So, for an organisation to be recognisable and acquire better reviews in the corporate world, it should first master the corporate language. Dimeski (2016) found out that companies in Macedonia have not acquired knowledge of $\mathrm{BE}$ in communication, international trade, and interaction with people from different cultures. People working in the companies do not show BE skills when communicating since English is not their native language. Lack of intercultural awareness and skills may lead to misunderstanding and confusion that can harm business relationships and international trading (Winardi, 2015). Most of the time, traders major their communication in general English, which is insufficient for effective business. Although traders developed business English primarily for business reasons among English-speaking and nonEnglish speaking trades, traders in Macedonia have dragged in native languages with time. Hence, Macedonian companies are not fully equipped with people that can make a difference in the country when they participate in the business.

Therefore, based on Dimeski's (2016) arguments, if companies in Macedonia adopt business English, it will advance their economy and help to improve intercultural skills. Besides, it can help solve the rampant issue of cultural diversity in the community and promote professionalism. Furthermore, those with BE knowledge will also understand the business world better and improve communication skills. These different roles and the importance of introducing Business English as a lingua franca in Macedonian companies are explained below.

\subsection{Business English as a Lingua Franca}

In the past decade, many scholars and researchers such as Nickerson (2015), Seidlhofer et al. (2012); Jenkins et al. (2011); Mauranen and Ranta (2009) have discussed the use of English as a lingua franca, or a common language for communication globally. Jenkins (2011) states that the term lingua franca was first used by the Italians between the $15^{\text {th }}$ and $19^{\text {th }}$ centuries. The term lingua franca signified a conglomeration of Italians and had a smattering of different languages, including French, Greek, and Spanish. At first, lingua franca was used as a language among business people who at no time shared a native language. Referring to Haberland (2011), lingua franca is in two approaches - micro and macro-sociolinguistic approaches. The first one explains that it is used by speakers of different languages as a communication tool. The second approach states that lingua franca is a language of religion. Jenkins et al. (2011) concluded that lingua franca is a tool of communication used by people from diverse native languages. This means that even native speakers are included. Jenkins et al. (2011) explain that Business English as a lingua franca is different from English as a native language, including native English individuals.

Currently, BE has become a lingua franca all over the world. Business English as a lingua franca (BELF) has been getting more and more attention in Macedonia as well, especially since many foreign companies are trying to implement it at an administrative level. BELF is defined by Seidhofer (2009) as a neutral language of communication between business people whose 
English is not their first language. Seidlhofer found out that the main focus of BELF in today's world is to achieve effective communication grounded on common understanding in a diverse context. According to $\mathrm{Wu}$ (2013), BELF substitutes BE because BELF covers teaching and researching concepts. Its main purpose is to facilitate business communication between native English speakers and non-native English speakers. However, Crystal (2003) found out that this is only applicable in a small amount of BELF interactions since most Native English speakers contribute to up to $25 \%$ of the total global English users. According to Louhiala-Salminen et al. (2005), no one can claim BELF as their mother tongue. It is used to conduct business within the global business community.

\subsection{Importance of introducing BEFL in Macedonian companies}

\subsubsection{Solving the issue of cultural diversity}

Apart from specialisation in business, Gajšt (2014) found out that for international businesses to be successful, people involved must be aware of each other's culture. Like in any other place, companies in Macedonia engage in business with people of different cultural diversities, which refers to the existence of different cultural groups in one society. In the modern world, where telecommunication advancements exist, cultural diversity has become a significant bottleneck in pursuing societal progress. This obstacle is mainly encountered in multicultural societies such as the Macedonian. Due to different cultures in the community, the various individuals use different languages; hence, communication cannot flow smoothly. Therefore, Gajšt (2014) says that there is a need to communicate effectively with people from diverse cultures and understand how ideas are expressed in international business. This can only be solved if people embrace Business English as a lingua franca (BELF).

Tannen (1984), on his side, found out that communication aspects are different in cultures. If other cultural groups do not understand communication aspects, it may lead to poor communication and misunderstanding, especially when people engage in business. Poor communication is a significant concern and can lead to stunted growth in society. Often, individuals have great ideas that can only be actualised while working with others and understanding each other. In that regard, the Innovating Education and Educating for Innovation Research by OECD in 2016 presents a survey where writing and speaking a foreign language is listed as a critical skill for the most innovative jobs. In the research, a neutral language is regarded as the best way to understand other cultures.

Moreover, poor communication can negatively affect business transactions, as the individuals transacting have to be using the same language. This idea is shared by Lewis (2006), who majorly explains more about culture and their communication patterns, especially in the business environment. In his book, Lewis says that people from different countries use language differently, bringing different thinking and behaviour patterns. Since people understand things differently, cultural diversity may lead to many unresolved conflicts and misunderstandings in society. The unresolved disputes, mainly in companies and international businesses, lead to work inefficiency among employees, which later translates to low profits, layoffs, and other serious consequences for the businesses. To avoid cultural collisions, Lewis concludes that business people must be aware of the potential misunderstanding in communication and find ways of solving them. This can only be achieved if a neutral language is used, which in this case is BELF. 
Also, cultural diversity can lead to increased social tension, which has been the case in Macedonian society for years. Over the years, minority cultural groups have been facing, or feel that they are facing, much social pressure from the majority cultural groups. For instance, in areas where Christians are the dominant religion, the other religions present, such as the Muslims, may feel that they have been neglected and discriminated in various occasions, and vice versa, for that matter. Additionally, during political events such as elections, individuals from different cultural groups often are not represented in political life, so they always blame each other when their favourite candidates are not elected. This feeling of inequality sometimes even leads to a civil war, which is a significant blow to societal advancement.

Suppose the society in Macedonia will embrace BELF; individuals from different cultures, especially those engaging in business, will learn the same language, thus having some related cultural values. Winardi (2015) explains that the relativity of cultural beliefs resolves the issues caused by cultural diversity. In their study, Winardi (2015) and Chan (2020, p.47) found that society can solve poor communication problems if they use the same language since speakers can communicate effectively. Further, on unresolved conflicts, individuals and employees working in Macedonian companies can feel closer to each other; thus, they can resolve any differences among them in a much more peaceful way. Also, concerning social tension caused by cultural diversity, business English as a lingua franca helps ease such uncertainty, as the language unites the different cultures. Hence, with the resolved problems of cultural diversity, the community and Macedonian companies can advance the country's economy and create a society that integrates all cultures and peoples.

Furthermore, Business English as a lingua franca will enable companies in Macedonia to understand the corporate world better. This idea is emphasised by Gak (2019), who says that a better understanding of the corporate world is essential for each organisation as it gives them a competitive advantage. In this case, it shall give the business entities in Macedonia a competitive advantage over their rivals in the global industry since they understand the industry better. Therefore, individuals and organisations' improved understanding of the business world in Macedonia will ultimately lead to an advanced economy and business.

\subsubsection{Facilitation of international trade}

Communication in business situations aims to achieve business objectives, which, according to Gajšt (2014), aims at reaching agreements and making deals. Gajšt (2014) further says that, apart from being used in written communications, business English when it is a lingua franca it can also be used in spoken interaction with stakeholders. The spoken interaction can be in socialisation, negotiations, and meeting with people from an international context. In international trade, language is vital. People have to understand each other using the same language to transact on business matters effectively. BELF, when used by business parties in an international context, can help them communicate in the same language, thus understanding and successfully cooperating (Jenkins et al., 2011).

BELF has various benefits to international trade, as explained by Gerritsen and Nickerson (2009), Sing (2017), and Martins (2017). Referring to a study done by Gerritsen and Nickerson (2009), BELF has played a dominant role in international business transactions in the last two decades. The study found that BELF is necessary for speakers from different countries and whose English is not their first language. With BELF, these international speakers have been able to share ideas and engage in trade. Another study by Martins (2017) on "perspectives on business English as a lingua franca in business communication" showed that if companies focus on the use of BELF, they can easily share ideas necessary for any international business. According to Peng and Wang 
(2020), the global status of the English language has raised the need for business English. As many organisations are trying to go global, they consider business English as essential as it is the language used in carrying out business in different countries. Another study by Sing (2017) realised that BELF acts as an "umbilical cord of cultural diffusion," which means that all first languages are diffused. As a result, speakers end up speaking one lingua franca. In the end, it increases the volume of international trade. This has helped international traders to enhance their communication practices in their international business transactions. In addition, implementing BELF in the companies can play a crucial role in achieving this progress. The enhancement of global trade enhances society's growth. The advancements include economic growth in the community, initiated by increased exports. Finally, there is technological improvement in society as countries can quickly transfer technology from better-developed business partners.

Therefore, if companies in Macedonia understand the importance of BELF, they will be able to view their international business parties as belonging to the same cultural group due to the shared language. Moreover, this relativity in language will improve harmony among the business parties as individuals form solid bonds amongst the business parties. Also, business parties can more easily formulate laws and principles governing international trade and enforce them when both parties use the same language compared to when they use different languages. Thus, the benefits of international trade manifest societal progress.

\subsubsection{Communication skills and professionalism}

In the corporate world, just like in the everyday world, communication is critical. Communication is a critical factor in the business, or as Lovlyn, in her research in 2017, concludes, "...transfer of understanding from one person to another is viewed essential for the continued growth, survival and existence of an organisation". Furthermore, since the companies rely on individuals, the individuals must have business English skills to transfer the information clearly and successfully. Therefore, every member in the corporate world should have the requisite tools and skills for efficient and effective communication. Hence, the knowledge of business English will greatly enhance business communication skills, explicitly required in the business environment.

By studying and using BELF, Dimova (2005) says that society and especially people working in the companies are prepared and equipped with the required skills for effective and efficient communication in the corporate world. Dimova (2005) further says that communication skills can also be evident in how information is presented in televisions/radio broadcasting and print media. Usually, an individual who is fluent in business English has the upper hand in the corporate world. Due to their communication skills, they can easily understand clients, explain and present their business ideas or products, and effectively and efficiently bargain with the client.

There have also been cases where companies decline to employ people who do not have business English communication skills. This is proved by a study done by Martins (2017). The study found out that $89 \%$ of employers in international companies prefer to employ people who speak the English language up to a certain level since these are the people with improved communication skills. By employing staff that has BELF knowledge, companies reduce the expenses of training and reach international audiences. Also, employees easily achieve technical skills and experience through training and development programs; thus, it is cheaper and timesaving. Therefore, if Macedonian companies understand a neutral language, which is BELF, they will also be able to target international audiences using perfect business English. 
Additionally, BELF skills give employees an added advantage over their peers, as they are more confident in expressing themselves due to their eloquence in business English. A study by Chan (2020) showed that BELF improves the level of confidence among employees. Confidence is critical, especially at an individual level. It determines how a person expresses themselves to others during presentations or interviews; candidates eloquent in business English are confident about themselves. Such individuals are also knowledgeable and aware of all the terms and vocabularies used during the interview. In another study on "business English lingua franca in intercultural (business) communication," Kankaanranta (2008) realised that communication skills are crucial if companies want to achieve their goal and prosper in business. Additionally, employing BELF equips business staff with skills that lead to improved communication skills in the corporate world, which ultimately translates into profitable corporations.

Even though learning general English is an advantage for business English students, Gak (2019) found out that making it a lingua franca would help society gain knowledge and understanding of complex business terms and vocabularies. These terms and vocabularies could not have been learned in just studying the general English language. Furthermore, if business English as a lingua franca is adopted by Macedonian companies, the staff and stakeholders involved will be more eloquent in the corporate language. As a result, their companies will be considered professional by the different entities in the corporate world. Just like wearing official suits by managers is deemed proficient, mastering the corporate language by the managers is also regarded as professional. Professionalism in the organisation comes with certain benefits such as; increased faith in the customers concerning the organisation; customers always believe that professionals produce high-quality services; thus, they will prefer to transact with a professional organisation instead of unprofessional ones.

\subsubsection{Facilitates cooperation, teamwork and organisation goodwill}

The basic foundation of cooperation and teamwork is the sharing of the same vision and goals. Sharing the vision and goals in society at large or at an organisational level is affected by sharing cultural aspects such as language. For example, a study by Sharma (2020) concluded that societal members, including coworkers, clients, business partners, could harmoniously work together because of the shared language. In addition, the organisation can easily enforce the various policies and guidelines formulated, as all the members of an organisation understand the language used. Cooperation and teamwork in the company come with numerous benefits, such as strong interpersonal skills. As employees cooperate in dealing with the assigned tasks, Sharma continues to explain that they can learn from each other, thus improving their technical skills and knowledge. The improved abilities later lead to a well-skilled and equipped workforce, therefore, increased productivity.Additionally, employees can handle complex tasks with ease as different employees have unique skills and experience. When they are teamed up, they form a strong workforce that can handle any job. Sharma (2020) also found out that teamwork helps in uprooting hidden employee skills and abilities, such as leadership skills. That being said, business English as a lingua franca in Macedonian companies will encourage teamwork. Due to BELF, businesses and society can enjoy the benefits of cooperation and teamwork among employees in organisations and individuals in the community and international context.

Business English as a lingua franca can also help in raising organisational goodwill. Goodwill raises the value of the organisation. According to Kralova and Dolezelova (2020), investors and financiers majorly focus on the firm's worth when choosing the firms to invest into or to finance. Therefore, investors can only invest in companies that have improved goodwill rather than those 
with lowered goodwill. Additionally, improved goodwill sets the organisation apart from the competition for the most skilled and experienced employees in a particular industry (Tan, 2007). Usually, in certain professions and especially in the knowledge industry, an individual is always perceived as more quality in terms of skills and knowledge. Since most organisations compete for the individual's services, the qualified employee is more likely to choose the organisation with a good public reputation because they are the best; thus, they would like to be associated with the best organisation in the industry. As argued in the paper, among the various required qualities by the business organisations, the knowledge of business English is considered essential in the business world. Hence, when an organisation's staff is fluent in business English, the organisation's goodwill tends to improve as many people consider business English a professional language. Therefore, every company in Macedonia has to work on its public image and its corporate reputation.

According to Lassar et al. (1995), when a company incorporates BELF into its culture, the public perceives it as a well-established organisation, thus improving goodwill or corporate reputation. The higher goodwill comes along with many benefits for the company, including increased brand loyalty among customers. Loyalty will enable Macedonian companies to maintain and control a particular market share, thus prosperity. Therefore, Macedonian companies should encourage students to accept business English as a lingua franca and learn it in secondary and at the university level. The educational institutions incorporating business English in the syllabus help students grow their careers and increase their chances of being employed in the cooperate world. For example, suppose business English is made a lingua franca in the Macedonian corporate world. In that case, students and company staff will be equipped with the knowledge necessary to be employed anywhere since they have learned specific communication skills.

Finally, goodwill encourages forgiveness from both the public and the authorities. When an organisation has always been going the extra mile to serve its customers with quality goods and services, when inefficiencies occur sometimes, the customers will likely understand the situation. Moreover, when an organisation has been adhering to the set policies, it can be easily pardoned in case of noncompliance. All these benefits of improved goodwill will accrue to Macedonian companies if they incorporate business English into their culture.

\subsubsection{Strategies discussed by other researchers}

Introduction of business English in learning institutions can significantly increase business English's chances of becoming a lingua franca in Macedonian companies. Nickerson and Planken (2015, p.20) say that companies like those in Macedonia can work together with higher learning institutions to promote transparency and accountability. The transparency leads to increased credibility of the results. Improving credibility boosts employers' confidence in the graduates; hence they can be easily absorbed in the job market. Therefore, educational institutions in Macedonia have to advance their current courses and programs and assess their effectiveness to bridge the gap between what is provided by them and what is required by the business community (Andrade 2020). Furthermore, they can enhance the learning of business English through the implementation of blended learning, which incorporates physical and online-based learning in higher educational institutions. Such incorporation can lead to easier access for working adults and a broad scope of students; thus, the higher learning institutions can admit many students and potentially work with higher quality and more skilful students. Suppose business English is introduced in the curriculum; they will help galvanise the business 
environment in the country, which will lead to advancing the Macedonian society and improving the standard and quality of living.

Figure 1: Business English as lingua franca conceptual framework

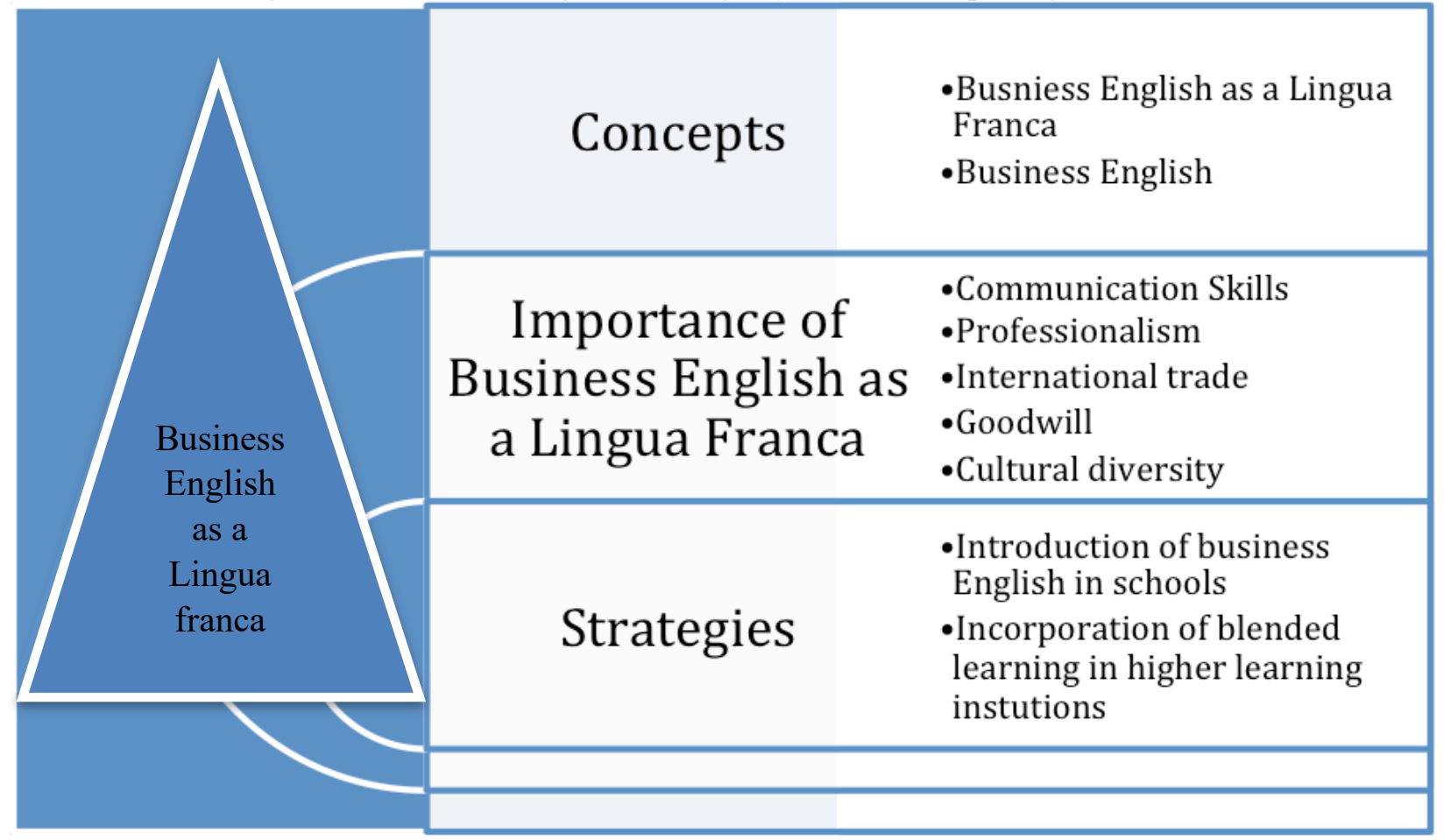

\section{METHODOLOGY}

The knowledge of business English as a lingua franca (BELF) in Macedonian companies was based on insights drawn from three different research methodologies. First, knowledge was obtained from research carried using surveys such as structured interviews and survey questionnaires. Second, the researcher also discussed activities that involved experimental research and, finally, two case studies have been analysed. Under discussion, the researcher discusses how the three types of research contribute to the knowledge of business English as a lingua franca in different companies and corporations. On the other hand, since not many studies are conducted on BEFL particularly for Macedonian companies, the researcher extends the discussion to other studies conducted in China and Germany.

For survey research in Macedonia, the researcher analysed an unpublished study conducted in 2017 and presented at a conference in 2018 in Plovdiv, Bulgaria by Dimeski who argues that teaching business English should be learned as a core competency for the students. Dimeski (2017) discusses "the need to understand that business English is among the core skills required by the companies for their employees." The study analyses responses from managers from twelve Macedonian companies, ten university professors teaching Business English and seventy-five Business and Economics students regarding the importance of business English proficiency, in order to create a student-centred curriculum that will include students' wants and needs, however the recommendations from the companies as well. The survey revealed that not only Macedonian companies prefer graduates with a high level of English proficiency but also rate the importance 
of English proficiency in the workplace as essential. In addition, business representatives responded that they expect the graduates to be fluent in English. Furthermore, Dimeski (2017) found that Macedonian companies require changes in the educational system regarding the Business English course. Thus, they believe that higher education institutions in the country have to make Business English a compulsory and core course for the students so that they are proficient and competent in communicating in English.

In addition, the survey research of Sonja Vandermeeren's in 1998 and 1999 has been analysed. Vandermeeren's work is discussed by Gerritsen and Nickerson in 2009. According to Gerritsen and Nickerson, Vandermeeren conducted a study involving several companies from different countries for three key reasons; to evaluate the language patterns from each corporation, whether there existed a link between them, and why certain patterns existed. The data was collected on a large scale through the use of questionnaires. It involved countries such as Germany, France, Hungary, Portugal and Netherland. The survey conducted in 1993 and 1994 in the five countries aforementioned for car companies and electrical industries resulted in 415 responses from corporations. The overall results indicate that many corporations used English as their business language. However, other languages were also considered important and relevant and were sometimes used instead of English. For example, around $42 \%$ of the companies located in France used German-language when transacting business with German corporations. The researcher also found out that approximately $30 \%$ of the German companies used English, and $25 \%$ reported to have used French when transacting business with the French companies. Vandermeeren revealed that English did not dominate as a lingua franca across the corporations. Instead, the study showed that English was used together with other native languages. In fact, in 1993 and 1994, German-French corporations did not use Business English as a lingua franca. Instead, several corporations preferred to use the first language of their business partners. Charles and MarschanPiekkari (2002) conducted similar survey research on Kone Elevators. Their study used extensive surveys and interviews to investigate the middle management of Kone elevators in Finland. The survey was meant to investigate the company's language policy, which involved adopting English as a corporate lingua franca. It involved 110 staff who were interviewed on the use of English and the challenges they encountered. English had been in use in the company for over 30 years, yet the employees interviewed claimed that there were still problems in communication. The difficulties in communication were caused by the diversity of different Englishes. Business English as a Foreign Language (BEFL) and Business English as a Second Language (B)ESL speakers had less difficulty in communicating and understanding their colleagues in BEFL and (B)ESL than they did with the colleagues who were Native speakers of English (NSE). The researcher recommended raising awareness of integration and use of BEFL and (B)ESL among the colleagues who spoke NSE.

English as a business lingua franca in a German multinational corporation is a study conducted by Sussane Ehrenreich from Ludwig-Maximilian's University Munchen Germany. The data for this study was obtained between 2006 and 2007 on the language and communication perceptions among employees at TechComp company. Specifically, there were 24 interviews conducted, observations of meetings comprising 16 events on board members and engineers from the TechComp. Some of the interviewees were from Germany, while others had Italian, British and American nationalities. Business English is not the official corporate language in TechComp, but its efficacy is a must for managers and top management down to other regular workers. The findings show that English use in corporations is a must for a general understanding of all the staff at all levels. In fact, Ehrenreich (2010) proposes that all staff need to develop English language skills to enhance their performance and role within the company. Also, it is not 
necessary to learn English as a native language but as a way of communicating effectively within the company setting. Therefore, apart from the strategy of learning business English in the context of enhancing communication, it is also essential to ensure that the native languages are not eradicated but used as strategic resources that complement business English.

Further, the researcher also discusses the experimental research that focused on English accents previously carried in Radboud University Nijmegen by Nejjari, Gerritsen, Van der Haagen and Korzilius in 2012. Nejjari et al. claim that the British Native speakers of English (NSEs) could comprehend well the sentences uttered by their colleagues with a Dutch accent. However, this depends on the first language of the English as a Foreign Language (EFL) speaker. Those that closely resemble English were found easy to understand. The use of experimental methods in such a field is faced with several limitations, such as texts which can easily be manipulated, and responses may respond differently under real-life situations and when in an experimental setting. In that regard, data collected using experimental studies require complementation with real-life observations. For experimental studies among the BELF and EFL, more research is needed to understand the use of English as a lingua franca.

The researcher also focused on a case study conducted by Manachai Inkaew from the Rattan Bundit University, Bangkok, Thailand. Manachai performed a case study to understand how English is used as a Lingua Franca among the non-native speakers for mutual understanding in international Golf Tournament Operations in Thailand. The case study analysis by Manachai on English as a lingua franca during an international golf tournament in Thailand is a landmark in which case study analysis is the primary methodology. He evaluates how successfully English is used as a lingua franca among non-native speakers with different language backgrounds. Data in this study was obtained through interviews conducted on ten personnel selected from the international golf tournament. Five personnel were from the Thai working team, and the others were from the organiser team. Participants from the organiser team were from different countries. The study aimed to explain how people with varying language backgrounds can achieve mutual understanding in a golf tournament and execute their work effectively. The language barrier issue is unavoidable in any setting where diversity of race and language is upheld. However, the issue of a language barrier cannot be an obstacle in executing the mandate and mission of the industry. Manachai established that the people who participated in the research perceived English positively though they lacked confidence. However, the participants argued that some terminology used in the field, accents, and limited words, disrupted their communication. In his study, Manachai discusses several strategies that can help to achieve mutual intelligibility for all parties. Some methods that effectively enhance mutual understanding where language diversity is embraced within an industry are using simple English words and choices, body language, and repeating words and sentences.

\subsection{Findings}

Most of the workers in Macedonia rarely use business English as a primary language of communication at their place of work. The gradual shift of most tech companies worldwide from using their native languages to business English as lingua franca is overwhelming and poses a challenge to countries such as Macedonia, who still, to some extent, embrace their native languages. Of course, we do not suggest replacing and eradicating the native languages used by companies in Macedonia. Instead, with the speedy diversity across the business world, it is perhaps the right time for Macedonia to incorporate and embrace business English in their corporations. This is not necessarily saying that people should only communicate in English; in 
extensive studies, business English as lingua franca fits well in a diverse corporation society that still values its nativity.

Understanding business English is vital for successful interactions and efficient running of activities at the workplace. It also starts with what Gajšt (2014) refers to as comprehension of ideas. If ideas cannot flow effectively from one person to another, accomplishing the mission and reaching a company's goals is obstructed. Poor communication has devastating outcomes such as stunted company growth, unresolved conflicts, misunderstanding (Lewis 2006), and poor actualisation of the right plans and ideas. All these setbacks translate to low profits and more severe disadvantages for the businesses.

Business English as a lingua franca plays a vital role in the facilitation of international trade. It creates a fairground of communication where people from different backgrounds can interact and share information without anyone feeling compromised or excluded. Gajšt (2014) shows how powerful it is to have strategies that advocate for BELF in businesses. Gajšt and other researchers like Gerritsen and Nickerson (2009), as well as Sing (2017) and Martins (2017), say that proper communication in business interactions is not limited to making deals and agreements, but still is effective in negotiations and interactions that involve international trades. The importance of incorporating BELF for companies in Macedonia creates a better avenue for these companies to grow and operate internationally. For example, a scenario is given of a TechComp company that operates in different parts of the world. In such a corporation, the use of business English as a primary mode of communication is mandatory; to enhance understanding. To achieve mutual understanding, all the stakeholders need to work together towards attaining a similar goal. The research carried by Manachai showed that to achieve similar goals all the personnel need to have a shared way of communication. Even though some challenges such as lack of confidence can interfere with communication efficiency, it gradually fades as everyone becomes eloquent. In that regard, Macedonian companies, especially the leaders, have a role to play. They need to introduce business English as means of communication within their companies. Change is inevitable, and with proper strategies, business English will be a culture embraced by all people with different language backgrounds.

\subsection{Proposed strategies}

Based on the aforementioned research and findings, several strategies can be implemented to ensure business English becomes a lingua franca in Macedonian companies. The strategies concern the companies and the educational institutions and they both have to play its role in the implementation of BELF.

\subsubsection{Employment of staff with English skills and training of employees}

Macedonian companies should be considerate when hiring new employees. Since diversity is encouraged across several major corporate sectors, there is a need to ensure that employees with proficient English skills are part of the stakeholders. Having employees who can eloquently speak English, especially business English, is a significant step in bringing change. Such employees are more likely to educate others during their interactive sessions. Also, when employees realise that a company aims at having workers who can communicate in business English, all the individuals shall strive to acquire the skills to maintain their positions and remain competitive among the other workers. Therefore, companies need to train their employees and 
other stakeholders on business English to ensure uniformity in communication skills across all the employees.

\subsubsection{Introduction of business English in secondary and tertiary institutions}

General English knowledge is insufficient, and the need to comprehend and communicate business English effectively is paramount. In order to ensure there is advancement in economy and business, there is an urgency to have an education system that supports business and economy. As students graduate, they need to have business English skills to be productive in corporations and offer quality services. This plan could work even more effectively if the institutions implement blended learning and increase levels of transparency and credibility. The learning process should entail what Ehrenreich (2010) proposes; learning English as a communication strategy and not necessarily as a native language. This diversification of business organisation is advantageous to the graduates as they can easily get their dream job from the available variety of opportunities globally due to the appropriate knowledge, skills, and abilities they have obtained in an appropriate learning environment (Andrade, 2020). Brindha, in their research published in 2017 entitled "Why business English," explains in detail the benefits of gaining knowledge in business English and argues that business English makes entrepreneurs more confident and increases their chance of achieving success. Similar benefits of having business English taught in school are expressed by Sharma (2020). Sharma states that "students having wonderful skills in Business English and communication would always be in demand." then he goes further and adds that thanks to business English, "you can explore your business nationally and internationally."

\subsubsection{Embracing language diversity}

Embracing language diversity is the first step of ensuring that a company values business English as a Lingua Franca. When the key stakeholders embrace language diversity and ensure that all the stakeholders are satisfied in the workplace despite their differences, it is easy for them to appreciate the usefulness of having a common business language. Therefore, it is important for stakeholders, especially the leaders, to ensure equity and equality across all the departments. This approach will make all the stakeholders comfortable and feel that they are part of the change.

\subsubsection{Use of simple wordings and body language}

English, like other languages, has complex words that are challenging even to native speakers. The use of complex wordings when communicating limits the participation rate and prevents understanding one another quickly. In that regard, business English as a lingua franca in Macedonian companies should first involve using simple vocabulary that is easy to understand. It is also essential that the communication is founded on the repetition of words and statements to avoid misunderstanding and misinterpretation. In addition, communication should involve body language. Integration of body language, simple words, and repeating statements makes it easy for members to understand each other and execute plans having similar objectives. Implementing the proposed strategies can be significant in bringing change to Macedonian companies and ensuring that business English becomes a lingua franca. 
Figure 2: A proposed strategy for BELF in Macedonian companies

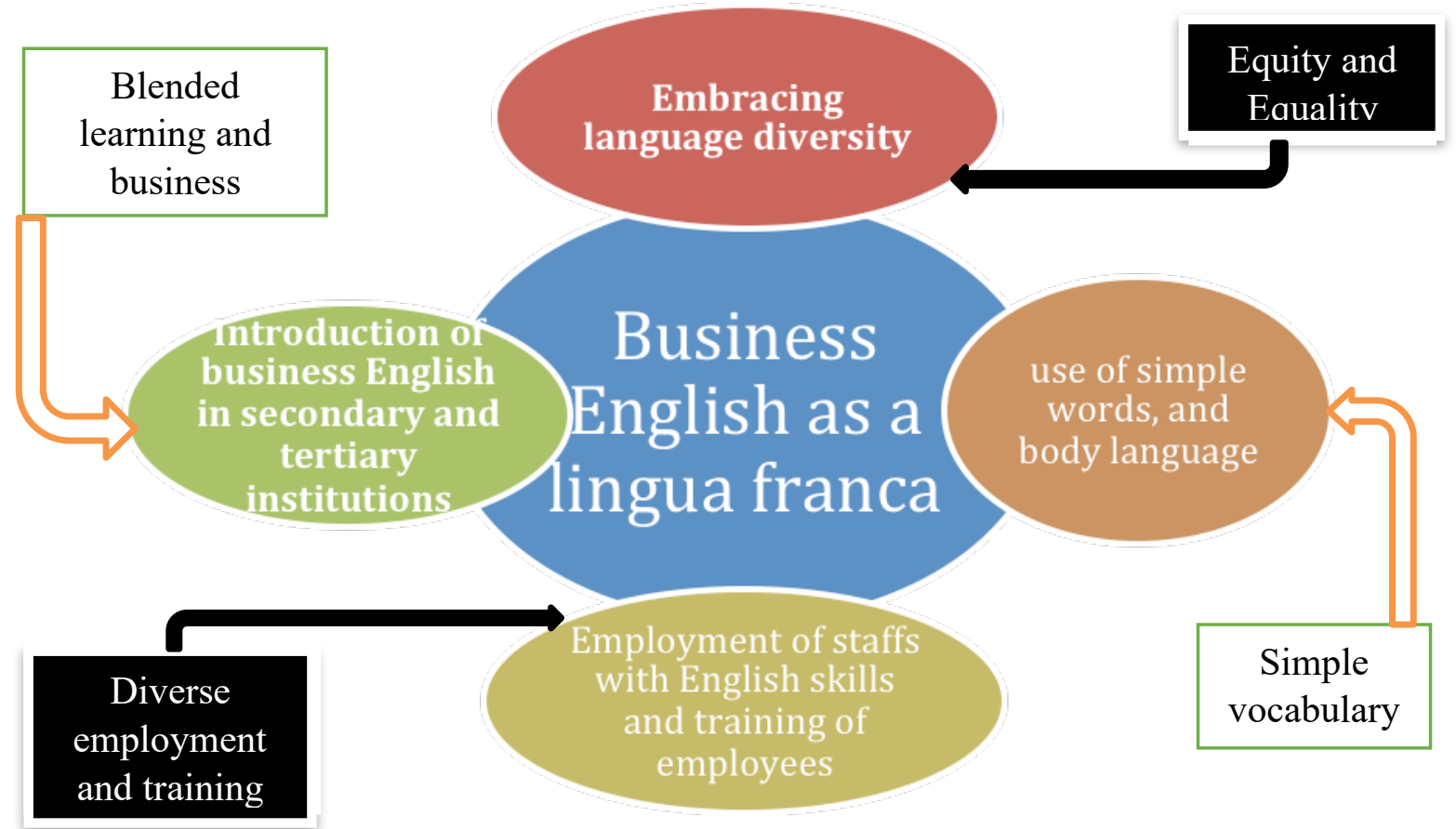

\subsection{Limitations}

The study had two main limitations; little is discussed on business English as a lingua franca in Macedonia. Secondly, the research relied on research carried by others and not data drawn from the Macedonian companies. There is little literature discussing English as a lingua franca for companies and corporations in Macedonia. Therefore, this study relied on outside studies rather than those conducted in Macedonia to develop a future strategy. This implies that it based its arguments, discussion, and conclusion on studies conducted by other researchers. The findings of these researchers probably could not be generalised to all the countries across the world. However, most businesses worldwide operate their communication using a lingua franca that is understood by a significant portion of stakeholders. Among the commonly used lingua franca is business English which many companies across the world currently embrace.

\subsection{Recommendations}

There is a need to develop a curriculum that encourages students to learn business English while in school. Teaching students on different varieties of English, students become conversant with the English used in the business world. Therefore, schools in Macedonia should include English used in the business world, ranging from English as a Second Language (ESL), native speakers 
of English (NSE), and English as a foreign language (EFL) as part of the curriculum. Therefore, to advance the economy and business, the educational system has to be advanced so that when students graduate, they are highly qualified and skilful for the available job opportunities both $\mathrm{n}$ and globally.

It is also recommended that the Macedonian companies ensure that the stakeholders are aware of the impacts of culture. Culture is conservative and aggressive and, erosive changes are strongly resisted. Some employees have strong beliefs about their cultures, such that if what they think is wrong as per their culture is considered correct in the organisation, they are ready to quit. Also, some employees are unable to work peacefully with other employees from different cultural groups. This difference leads to many employees resigning, which is costly to the organisation, as it will use more money to recruit new employees. Therefore, Macedonian companies have to personally train and develop recruits who are graduates and well equipped for the job. Proper selection and training will help Macedonian companies reduce the high turnover rate caused by a lack of BELF knowledge.

\section{CONCLUSION}

There are numerous benefits of business English as a lingua franca; therefore, the researcher aimed at proposing a strategy that could be used in implementing business English as a lingua franca in Macedonian companies. The importance of the introduction of business English as a lingua franca is to improve communication and satisfy the target audience's needs for companies in Macedonia. There is no better and more stable way of advancing society than educating the people since the human resources of any country are the backbone of the development and the future of that country. That is why this paper proposes a strategy for the future of the Macedonian societal development based on advancing the Macedonian educational system. Incorporating business English as the lingua franca in the business organisations in the country, as argued in this paper, shall significantly improve the business environment as well as the Macedonian economy. Although there are various ways of promoting education, incorporating business English in the syllabus is one of the main ideas proposed in this paper.

Business English is the international business language as it is applicable in international business transactions. However, business English is different from general English. General English focuses on day-to-day conversations; hence, it does not incorporate complex vocabularies, business and economics concepts, and phrases, nor does it prepare the learner with the essential business communication skills. On the other hand, business English focuses on the unique phrases and terms used in the corporate world. Therefore, being fluent in general English is not sufficient for a person to be able to perform business transactions in the corporate world. Consequently, individuals, especially if their career path is business-related, have to study business English in secondary and tertiary education, and after they acquire the knowledge of general English. Therefore, introducing Business English courses into the Macedonian educational system, both at the secondary and tertiary level of education, is key to preparing and developing a skilled workforce and knowledgeable university graduates ready to apply their competence in the business world.

The changes in the educational system are essential in promoting the proposed strategy in this paper for advancing the Macedonian companies. However, companies should not wait until those changes are implemented into the Macedonian educational system but work with society and the authorities to present and explain the benefits of the changes. In other words, the business entities should gradually start to implement business English as the lingua franca into their business organisations at different levels in their organisational structure. In addition, companies have to 
start with training the current workforce to be able to function in the new environment. Thus, by proper recruitment and training of the recruits, Macedonian companies shall have an adequate number of quality workers. Corporations should also consider promoting equity and equality across all departments. This makes all the diverse groups working in the companies feel wanted and valued. It becomes more of a once society though comprising people of different backgrounds. With diversity being embraced, the stakeholders can easily develop the need to have a common language of communication. It is also important for the companies in Macedonia to promote the use of business English as a lingua franca by first encouraging the use of simple English words and body language. This can be a good beginning to build a cohesive and comprehensive language where all stakeholders are comfortable with language policy. The use of complex words can result in some stakeholders dragging behind and perhaps giving up.

However, for the community to see the benefits of this strategy, business English must be incorporated both into the business organisations as well as into the syllabus of the Macedonian education institutions; thus, they can create graduates and workforce with employability and work-related skills, ready for the real business world. The benefits of this strategy for the Macedonian corporations include; improving an organisation's goodwill, solving the rampant issue of cultural diversity in the community, business leverage, students' career growth, more understanding of the business world, enabling graduates to get the job they want, increasing professionalism among individuals, improving communication skills among individuals and facilitating cooperation and teamwork both in the organisation and the society at large.

\section{REFERENCES}

Andrade, M. (2020), "Innovations in Higher Education - Cases on Transforming and Advancing Practice" Parrish, D. \& Joyce-McCoach, J. (ed.), A Responsive Higher Education Curriculum: Change and Disruptive Innovation, IntechOpen.

Brindha, S. (2017), "Why business English," IUP Journal of English Studies, 12. pp. 64-69.

Chan, M. (2020), English for Business Communication (1st ed.). London: Routledge. https://www.taylorfrancis.com/books/mono/10.4324/9781351060035/english-business-

communication-mable-chan

Crystal, D. (2003). English as a global language. Ernst Klett Sprachen.

http://culturaldiplomacy.org/academy/pdf/research/books/nation_branding/English_As_A_Globa 1 Language - David Crystal.pdf

Dimeski, N. (2016). Effective Business English Teaching at University Level in MacedoniaNeeds Analysis. Cataloging-In-Publication Data, pp50-59. http://ibaness.org/bnejss/2017 03 01/07 Dimeski.pdf

Dimeski, N. (2018). "Teaching and Learning Business English as a Core Competency-A Strategy for Enhancing the Skills of the Business and Economics University Students.", paper presented at International Balkan and Near Eastern Social Sciences Congress Series VII. IBANESS Congress Series, April 21-22, 2018 Plovdiv, BULGARIA, pp. 661. http://www.ibaness.org/conferences/plovdiv_2/ibaness_plovdiv_proceedings_draft_10.pdf Dimova, S. (2005). "English in Macedonia.", World Englishes, 24(2), pp. 187-202. https://onlinelibrary.wiley.com/doi/epdf/10.1111/j.1467-971X.2005.00403.x

Ehrenreich, S. (2010). "English as a business lingua franca in a German multinational corporation: Meeting the challenge.", The Journal of Business Communication (1973), 47(4), 408-431. 
Gajšt, N. (2014). "Business English as a lingua franca-a cross-cultural perspective of teaching English for business purposes.", in ELOPE English Language Overseas Perspectives and Enquiries, 11(2), pp. 77-87. https://revije.ff.uni-lj.si/elope/article/view/3171/2879 Gak, D. (2019), "Business English or Survival English?" in 10th International Language Conference on The Importance of Learning Professional Foreign Languages for Communication between Cultures, 20/21 Sept. 2018, Celje, Slovenia, pp. 121-128.

Gerritsen, M., \& Nickerson, C. (2009). "BELF: Business English as a lingua franca.", in Francesca Bargiela-Chiappini (ed.), The handbook of business discourse, pp. 180-192. https://www.researchgate.net/publication/289557702_BELF_Business_English_as_a_Lingua_Fr $\underline{\text { anca }}$

Goudswaard, G., Henderson, D. \& Streitwieser, V. (2018), Business English, München: Haufe Lexware Verlag.

Haberland, H. (2011). "Ownership and maintenance of a language in transnational use: Should we leave our lingua franca alone?", in Journal of Pragmatics, 43(4), pp. 937-949.

https://www.academia.edu/698341/Ownership and maintenance of a language in transnationa 1 use Should we leave our lingua franca alone

Inkaew, M. (2018). "An Exploration of English as a Lingua Franca Communication: A Case Study of How English is Used as a Lingua Franca among Non-native Speakers for Mutual Understanding in an International Golf Tournament Operation in Thailand.", in REFLections, 25(2), pp. 42-58.

Jenkins, J., Cogo, A., \& Dewey, M. (2011). "Review of developments in research into English as a lingua franca.", Language teaching, 44(3), pp. 281-315.

https://eprints.soton.ac.uk/186181/1/LT article.pdf

Kankaanranta, A. (2008). "Business English Lingua Franca in intercultural (business)

communication.", in Language at Work-Bridging Theory and Practice, 3(4).

https://tidsskrift.dk/law/article/view/6193/5381

Kralova, Z. \& Dolezelova, E. (2020), "The importance of English in business education in the Czech Republic." in Journal of Education for Business, 96(2), pp. 111-119.

Lassar, W., Mittal, B. and Sharma, A. (1995) "Measuring Customer-Based Brand Equity," in Journal of Consumer Marketing, 12, pp. 11-19.

Lewis, R. D. (1999). Cross-cultural communication: A visual approach. Transcreen Publications. 2006. When Cultures Collide: Leading Across Cultures. London: Nicholas Brealey Publishing Louhiala-Salminen, L., Charles, M., \& Kankaanranta, A. (2005). "English as a lingua franca in Nordic corporate mergers: Two case companies.", in English for Specific purposes, 24(4), pp. 401-421. https://www.sciencedirect.com/science/article/abs/pii/S0889490605000086 Lovlyn, K. (2017), "The Role of Effective Communication in Strategic Management of Organizations," in International Journal of Humanities and Social Science, 6. pp. 93-99. Martins, H. F. (2017). "Perspectives on Business English as a Lingua Franca in Business Communication.", in Teacher Education and Curriculum Studies, 2(5), 61. http://www.sciencepublishinggroup.com/journal/paperinfo?journalid=240\&doi=10.11648/j.tecs. 2 $\underline{0170205.11}$

Nickerson, C., \& Planken, B. (2015). Introducing Business English (1st ed.). London: Routledge. OECD (2016), Innovating Education and Educating for Innovation: The Power of Digital Technologies and Skills, OECD Publishing, Paris.

Peng, L. \& Wang, X., (2020), "Analysis of negotiation skills of Business English in international trade." 2020 International Conference on Educational Science (ICES2020), pp. 760-763. 
Rao, Parupalli. (2019), "The Role of English as a Global Language." in Research Journal Of English (RJOE), Vol-4, Issue-1, 2019, pp. 65-79.

Seidlhofer, B. (2005). "English as a lingua franca.", in ELT Journal Volume 59/4, October 2005. Oxford University Press, http://eltj.oxfordjournals.org/content/59/4/339.full.pdf+html

Seidlhofer, B. (2009). "Common ground and different realities: World Englishes and English as a lingua franca.", World Englishes, 28(2), pp. 236-245. https://onlinelibrary.wiley.com/doi/epdf/10.1111/j.1467-971X.2009.01592.

Sharma, G. (2020), "Ideology Of Business English.", in Topical Issues of Linguistics and Teaching Methods in Business and Professional Communication Conference, pp. 100-107. Sing, C. S. (2017). "English as a lingua franca in international business contexts: Pedagogical implications for the teaching of English for Specific Business Purposes.", in Handbook of Business Communication, pp. 319-356.

Tan, H. (2007). "Does the reputation matter? Corporate reputation and earnings quality." Working paper, China SouthwesternUniversity of Finance and Economics. iscep]

Tannen, D. (1984). "The Pragmatics of Cross-Cultural Communication 1.", Applied linguistics, 5(3), pp. 189-195.

Winardi A. (2015), "The Importance of Developing Intercultural Awareness in the Business English Classroom.", in Sino-US English Teaching, December 2015, Vol.12 No.12, pp. 964-968. Wu, Y. (2013). "Business English as a Lingua Franca (BELF).", in International Education Studies, 6(10), pp. 130 138. https://files.eric.ed.gov/fulltext/EJ1068643.pdf 